\title{
TRIBES ON THE UPPER NILE
}

\section{THE BARI}

THE country round Gondokoro and Rejaf is flat, and in the wet season one vast swamp; hills rise abruptly from the plain here and there and vary the monotony of the view. Further south, near Dufile, the country is mountainous and picturesque. The tribes who inhabit these regions resemble each other in many ways; their languages and customs are analogous and their wants are few, for civilisation has passed them by untouched and left them as they were before the white man came. In this respect they form a striking contrast to the inhabitants of Unyoro and Uganda further south.

Suspicion is inbred in all uncivilised peoples; but when once that is allayed you find the savage of Africa docile, intelligent, and very friendly.

The Bari, the subject of the present sketch, are no exception to the rule. They are naked savages, but by no means uninteresting; they live on the Nile from about Bor to Dufile, roughly speaking. To-day they are but the remnant of a once powerful tribe.

Ruins meet the traveller's eye on all sides-tangled grasses and jungle growing up between Dervish zaribas and stone defences mark many a spot, now deserted, where once the Bari sat and smoked his pipe in peace.

Several causes conspired to reduce the population; the chief of these were slavery, war, and plague. Sir S. Baker talks of Gondokoro as a hell filled with cut-throats and outlaws, whose only aim was to gain slaves and ivory. They infested the whole country and exported thousands of victims annually. 
The wars were incessant. All the tribes on the Nile are warlike, and the men for the most part do nothing else but fight, while the women till the land and the children tend the cattle, sheep, and goats.

The Bari fought against Sir S. Baker; and later, when Emin Pasha was cut off from Egypt by the Mahdi rising, he left the station in charge of a Soudanese officer, Rehan Effendi Aga, and made Wadelai his headquarters. In October of that year (1885) the Bari attacked Lado under the leadership of Befo, chief of Belinian. Later on Rejaf was also attacked, and in these fights the Bari suffered severely.

Emin had some 300 troops in the country, and these were recruited very extensively from the Bari; moreover, his soldiers acquired a numerous following. Emin himself relates how one of his officers had ninety-five people in his household.

After Emin came the Dervishes known to the Bari by the name of "Koteria." They quickly overran the country; ruin and pillage marked their progress, and most of the Bari chiefs fled with their people, some to the hills and mountains, others far into the Congo region. East and south the country was devastated, and the large herds of cattle captured never to be returned.

In the year 1894 small-pox broke out among the remnants of the Bari, and owing to the ignorance of the natives it carried off many victims; it is therefore only during the last few years that this tribe has settled down to a peaceful life and begun to recover from years of famine and disaster.

There are many of the Bari chiefs who knew both Baker and Emin. When the latter was at Rejaf he occupied himself more with natural history and botany than with ruling the turbulent chiefs and soldiery; indeed, his native officers seem to have acted very largely on their own responsibility. Some of the stories told of this period are curious and show that summary methods were employed in dealing with refractory natives. For instance, the chief "Loron," who lived at Gondokoro, had a big dog which he called Emin. This news reached Rejaf and the chief was sent for. He 
refused to obey the summons, and a native officer, Tiaka Effendi Muhamad by name, sallied forth with half a company, killed Loron and brought his head to Rejaf. Emin is credited with having given the order to bring in Loron dead or alive, but it is more than probable that he knew very little of what was going on.

In the space of a short article it is impossible to give any detailed account of the many customs of a tribe like the Bari; but I propose to mention briefly a few of the more important usages.

There is a good deal of cultivation, for which most of the islands of the Nile and the low-lying land on the banks are utilised: Dhurr (Sorghum vulgare) and Telabun (Eleusine coracana) are perhaps the staple foods, though sem-sem, ground nuts, Duku (Penicillaria sp.), beans, sweet potatoes, and other varieties of fruit are grown; oil is extracted from the two ground nuts known to the local Soudanese troops as Maniga and Karakédé (Arachis hypogaea and Hyphis spicigera); cotton grows wild in many parts of the country and is utilised by the natives; they also grow tobacco.

The women grind the Dhurra with flat stones, and the flour is made into a porridge, which constitutes their principal meal and is eaten after sunset. In times of plenty they also eat in the morning; but this is unusual, as the country is frequently in a state of famine owing to drought or excessive rains. The mention of rain reminds me of the rainmaker.

The belief in the power of causing rain is common to all the tribes on the Nile; it appears to be generally considered hereditary, and passes from father to son. The rainmaker is nearly always a chief, and soon acquires wealth in comparison to his neighbours by reason of the gifts proffered in lieu of his services. I remember when I was in the Latuka country, in the month of February, everything was parched with heat and the river Kos was dry. I found Limoro, the big chief, at Logguren, and I asked him why he was not residing at Tarangoli, his capital and usual abode. He gravely informed me that he had left Tarangoli to punish his people there who had disobeyed his orders. "And now," said he, "I will not give them any rain until they all come 
here and beg for it, and then perhaps I shall return to Tarangoli and let the rain fall." He firmly believed in his own powers, and laughed when I suggested that it was impossible.

The rainmaker generally ends by a violent death; the people are so superstitious that in seasons of great drought they assemble and kill the rainmaker, believing that it is he who refuses to let the rain fall. The operations when the rainmaker is called to any part of the country begin by his feasting with the local chief. His stock-in-trade is a stone about two feet long with a hollow in the centre, into which he pours water and the entrails of a sheep or goat freshly killed. He then dips his hand in and sprinkles a little of the water towards heaven. Should the rain fall 24 hours after, the medicine man is sent for. Among the Bari nearly every village has a medicine man, locally known as the "Burri." This worthy is about as capable as the rainmaker, and is generally old and cunning. He supplies charms, drives away devils, and counteracts witchcraft. The charms are worn by all the Bari, teeth of monkeys, pieces of wood or leather, or anything the Burri chooses to supply. He has two pieces of leather about the size of a finger, and, when called upon to help the rainmaker or do anything else, he gets a clear piece of ground either in a hut or just outside, and throws the leather pieces on the ground with a peculiar click of the fingers. Then he fills the bowl of a pipe with little beads or pebbles and casts these latter on the ground several times, each time picking them up and shaking his head ; ${ }^{1}$ after five or six times the Burri declares the performance over, and the evil eye, devil, or whatever it is duly exorcised.

When a chief dies his "Lugara," or drum, is beaten in the early morning, and the women of his family commence their cries of lamentation; the whole country-side assembles as the drum-beating is taken up in every village, and each mourner pays his last respects to the late chief by sprinkling

\footnotetext{
1 The wla, or "lot," found almost everywhere, usually under thil or similar designations, and performed in most cases by casting knuckle-bonea. See H. A. Junod, L'Art Divinatoire ches les Baronga-[ED.]
} 
a few drops of oil on the body, which is then buried just outside the door of the late owner's but. The obsequies over, a great feast commences with dancing and singing, and lasts several days, according to the wealth and importance of the deceased. The near relatives (female) wear wood ashes on the face for about a month as a sign of mourning. ${ }^{1}$ There is no belief in a future state among the Bari.

Hunting is a favourite occupation among the men; they assemble in large numbers in the morning, all bringing their nets, which are about eight feet high with large, strong meshes, and vary in length from thirty to fifty feet. Arrived at a suitable place, these nets are fixed upright, the poles of one net being fastened to the next, the whole making a barrier of perhaps half a mile in length. The hunters now divide, a number of men with spears crouch in the grass behind the nets and close to them; the remainder retire a long distance, and with parties on either flank drive the game into the nets, where they are speared.

For elephant, buffalo, and big game the manner of hunting is different. A herd of elephants is located, and the hunters assemble in large numbers. Armed with spears they then proceed to form an enormous circle round the herd, and at a given signal they fire the grass. This method can only be employed in the beginning of the dry season, when the grass stands about twelve feet high. As the circle of fire gets smaller the natives follow over the burnt ground, and when the elephants perceive the fire they rush madly from one point to another, endeavouring to escape. Some break through the flames, but many get burnt or suffocated, and of those who escape the flames some receive so many spear wounds that they eventually die. "The hunters follow up a wounded elephant thus for days, till he at last drops.

I once came on a solitary bull elephant who must have escaped from one of these fires some time previously. His skin was all peeling off, both his eyes were burnt, and altogether he was in a dying condition - the smell was intolerable.

\footnotetext{
' Compare the ufa sprinkled on the head during mourning by the Yaos.-[ED.]

"Is this quite certain? The opirits exorcised by the "Burri" are quite as likely as not to be spirits of the dead. - [ED.]
} 
He dropped to the first bullet, and I do not think he could have recovered.

The hippopotami in the Nile are speared from canoes, each spear having a long rope with a flost at the end. When the wounded beast sinks the hunters follow the floats till they get their game.

The Bari make rafts for the passage of the Nile; these are five poles of very light wood riveted together with bamboo; a man swims behind pushing the raft with one hand, and sheep and goats are passed across the river in this manner. Cooking pots are made of earth, and in many cases covered with designs and polished.

Pipes are made by the women in much the same way as the cooking pots. Salt is manufactured from papyrus and swamp grass, which is burnt and the residue soaked in water, which becomes salted and is sprinkled over food.

Salt is also obtained by the same process from the dung of cattle and goats. Iron-smiths make hoes and razors; the iron is found in quantities on most of the hills. Mats and baskets and various other articles are made by the women.

The Bari dwellings are all circular mud huts; the villages are very dirty, the people have no tribal marks, though many of the men and all the women have tattoo marks on the body. Ear ornaments are worn by both sexes; they generally consist of small brass or iron rings.

The Bari men wear no covering of any kind; they generally have iron or ivory bracelets and charms; the married women have a covering in front and behind. This resembles a few pieces of thin string; it is made from the bark of a tree, and the strings are neatly plaited together at the top. The whole is fastened to a cowhide belt which passes round the loins.

The Bari to-day number some 30,000 or more, and the population is increasing. I have many pleasant memories of days passed in this part of the country. Elephants, rhino, lion, and leopard are numerous, and the natives are pleasant fellows to deal with. 